\title{
Innovative capacity in micro, small and medium enterprises: Review of international articles on empirical research
}

\author{
Truong Thi Hoang Oanh ${ }^{1 *}$, Duong Ngoc Thanh ${ }^{2}$, Truong Thi Be $\mathrm{Hai}^{3}$ \\ ${ }^{1}$ University of Economics Ho Chi Minh City - Campus in Vinh Long, Vietnam \\ ${ }^{2}$ Can Tho University, Vietnam \\ ${ }^{3}$ Tra Vinh University, Vietnam \\ ${ }^{*}$ Corresponding author: oanhtth@ueh.edu.vn
}

\begin{tabular}{ll}
\multicolumn{1}{c}{ ARTICLE INFO } & \multicolumn{1}{c}{ ABSTRACT } \\
\hline $\begin{array}{l}\text { DOI:10.46223/HCMCOUJS. } \\
\text { econ.en.10.2.585.2020 }\end{array}$ & $\begin{array}{l}\text { The purposes of the article are to evaluate the current status } \\
\text { of innovation capacity studies and propose directions for future } \\
\text { research. Thirty - six articles in international empirical research } \\
\text { on business, in particular micro, small, and medium-sized } \\
\text { enterprises (MSMEs) were identified from Springer, Emerald, } \\
\text { and ScienceDirect. Findings reveal most studies on innovation }\end{array}$ \\
Received: July $22^{\text {nd }}, 2020$ & $\begin{array}{l}\text { capacity focus on two lines of research: determinants of } \\
\text { innovation capacity (process) and consequences on innovation }\end{array}$ \\
Accepted: August $15^{\text {th }}, 2020$ & $\begin{array}{l}\text { capacities (outcome). The quantitative approach is the dominant } \\
\text { research method. Some research directions are proposed that } \\
\text { cover outstanding themes as follows: (1) considering quantitative } \\
\text { research method, (2) exploring innovation capacity on the service } \\
\text { sector, (3) identifying innovation capacity on stakeholders in } \\
\text { supply chain perspectives, (4) delving into how firm results can } \\
\text { be affected in each type of innovation capacity, (5) examining the } \\
\text { mediator of specific types of innovation capacities in the } \\
\text { relationship between many other factors such as customer } \\
\text { orientation, or market orientation or/and corporate social } \\
\text { responsibility and / knowledge management and networking with } \\
\text { business outcomes in term of the supply chain perspectives. }\end{array}$ \\
Keywords: & $\begin{array}{l}\text { th } 2020 \\
\text { innovation capacity, small } \\
\text { businesses, MSMEs, review }\end{array}$ \\
\hline
\end{tabular}

\section{Introduction}

Small and medium-sized business growth is the foundation and driving force of the economic development of many countries (Donkor, Donkor, Kankam-Kwarteng, \& Aidoo, 2018). Thanks to the advantages of nature and scale, the types of small and medium enterprises are very flexible because they can be easily and quickly adjusted, changed tactics and new strategies to compete and develop in the uncertainty of the business environment. One of the weapons of competition, building core competencies for both business level (Cardozo, McLaughlin, Harmon, Reynolds, \& Miller, 1993) and the national level is innovation (Beaver \& Prince, 2002; Sandvik $\&$ Sandvik, 2003). Innovation helps improve and enhance the organization's performance, discover new opportunities in the business environment (Bakar \& Ahmad, 2010), form a competitive advantage (Naranjo-Valencia, Jiménez-Jiménez, \& Sanz-Valle, 2016) through new processes, systems, and products to adapt to the market, the competitive environment and technology changes (Utterback, 1994).

Researchers think that innovation helps to reach customers' needs more because innovation 
manifests itself in many forms such as ideas, methods, techniques, or tools that are applied more effectively and efficiently than before (Raghuvanshi, Agrawal, \& Ghosh, 2019). In business administration, innovation is essential to the survival of the business, by developing innovation capacity. Innovation capacity can be understood as the ability to create new or valuable knowledge or products (Zheng, Liu, \& George, 2010) and to know how to deliver that value to other businesses and its customers (Budhwar, Pereira, Mellahi, \& Singh, 2019). Therefore, innovation capacity is at the heart of what small businesses need to look forward to competing with more and bigger resources competitors. Many empirical studies on innovation capacity in the small business contexts have accomplished into two lines of research: determinants of innovation capacity (process) and consequences on innovation capacities (outcome). Although the number of reviews on innovation is not small, most do not pay much attention to innovation capacity in the context of small businesses. This paper aims to clarify the characteristics of innovation capacity in the case of small and medium-sized enterprises, including microenterprises, through a system of prestigious international articles on empirical research. The article structure is organized in four sections including Introduction; Research Methods; Research results and discussion; and Conclusion and future research directions.

\section{Research methods}

This article summarizes the empirical research results of international articles on innovation capacity in business, in particular Micro, Small and Medium-sized Enterprises (MSMEs). The articles are extracted from databases with highly respected academic and business journals such as Springer, Emerald, and ScienceDirect. Articles are selected based on the following criteria:

\section{Table 1}

Criteria for selecting articles in the review

\begin{tabular}{|c|c|c|}
\hline Criteria & $\begin{array}{c}\text { Select }(+) \text { or } \\
\text { Not selected (-) }\end{array}$ & Reasons \\
\hline Articles with empirical evidence & + & $\begin{array}{l}\text { Provide empirical results on the innovative } \\
\text { capacity of MSMEs }\end{array}$ \\
\hline Articles in peer-reviewed journals & + & Ensure quality articles \\
\hline Articles in English & + & Covers high replicability \\
\hline $\begin{array}{ll}\text { Articles in subject categories of } \\
\text { Business, } \\
\text { Administration and } \\
\text { Accounting }\end{array}$ & + & $\begin{array}{l}\text { Enhance practical contributions to the } \\
\text { sector }\end{array}$ \\
\hline $\begin{array}{l}\text { Innovation capacity within the } \\
\text { industry }\end{array}$ & + & $\begin{array}{l}\text { Contribute to the enterprise and industry } \\
\text { level }\end{array}$ \\
\hline $\begin{array}{l}\text { Innovation capacity is at the national, } \\
\text { international and individual scope }\end{array}$ & - & $\begin{array}{l}\text { Do not contribute to business or industry } \\
\text { level }\end{array}$ \\
\hline Research results at the project level & - & $\begin{array}{l}\text { Do not contribute to business or industry } \\
\text { level }\end{array}$ \\
\hline $\begin{array}{l}\text { Articles in the theoretical or } \\
\text { conceptual model theory }\end{array}$ & - & Do not offer empirical evidence \\
\hline $\begin{array}{l}\text { Working papers, conference papers, } \\
\text { books, handbooks, case studies }\end{array}$ & - & $\begin{array}{l}\text { Ensure articles quality and limit research } \\
\text { scope }\end{array}$ \\
\hline
\end{tabular}

Source: Data analysis result of the research

The implementation process consists of 5 stages. The first stage was to select articles from 
database journals and was limited to research papers with the keywords "innovation capacity" \& "small and medium enterprises", "innovation capacity" \& "Micro, small and medium-sized businesses" or "SMEs" or "small businesses". The total number of articles found was 859 . The following stage was to select the subject area of "Business, Administration and Accounting", and limit the time of the article published in the period from 2010 to 2020, the total number of articles decreased to 156. In the third stage, the articles were filtered through the title based on the criteria in Table 1, the number of articles decreased to 69. Next, the number of articles that continue to fall to 48 in the fourth phase is done through reading the abstract. In the fifth period, the author has read the full text of the articles. The number of articles excluded was based on the criteria in Table 1. Therefore, the final number of valid articles was 36 .

\section{Research results and discussions}

\subsection{Concept and classification of innovation capacity}

In terms of innovation capacity for small businesses, there are two lines of research: innovation is a process and innovation is an outcome. Therefore, there are two concepts of innovation capacity.

Innovation capacity as a process and is a component includes many activities that could be carried out to improve small business performance (Abdulai Mahmoud \& Hinson, 2012; Castela, Ferreira, Ferreira, \& Marques, 2018; Song, 2015). Accordingly, innovation capacity is the ability to continuously transfer knowledge and ideas to create new systems, processes, and products that benefit businesses and stakeholders. In other words, "Innovation is an improvement anywhere in the enterprise; not only in products, services, and processes but also on other factors such as leadership, personnel, communications, organization, marketing and any other activities" (Csath, 2012, p. 10). Small businesses have to be constantly involved in the innovation process to survive and thrive in a competitive environment. Therefore, the first research line consists of two cases. In the first case, innovation capacity is a component divided into three branches: direct impact on firm performance (Omri, 2015); or as a mediator for other factors in the enterprise to interact such as market orientation, corporate social responsibility (Abdulai Mahmoud \& Hinson, 2012) to connect each other to improve the performance of the business; or a component that affects another intermediary so that the business can achieve higher performance. In the second case, innovation capacity consists of many dimensions that combine and complement each other, contributing to the creation of innovation capacity - like the potential to create innovation results (Boly, Morel, Assielou, \& Camargo, 2014; Emre Yildiz, Murtic, Klofsten, Zander, \& Richtnér, in press; Martínez-Román, Gamero, \& Tamayo, 2011; Saunila \& Ukko, 2014; Taneja, Pryor, \& Hayek, 2016). The innovation capacity recognized by these authors is the contribution of many different elements including leadership, organizational culture, knowledge management, skills, management, optimization of external knowledge, and creativity of employees. Some other studies defined innovation capacity as a combination of competencies including academic competency, entrepreneurship, marketing, networking, knowledge-building competencies, change management capacity, development capacity (Forsman, 2011); service innovation, technological process innovation, management process innovation (Baba, 2012); Innovativeness and capacity to innovate (Tamayo-Torres, Gutiérrez-Gutiérrez, Llorens-Montes, \& Martínez-López, 2016); internal innovation capacity and open innovation (Agostini, Nosella, \& Soranzo, 2017); Resource exploitation capacities, resources, networking capacities, risk-taking and involvement (Raghuvanshi et al., 2019; Raghuvanshi \& Garg, 2018). Specially, the research and development index of small businesses is considered as a small part of the above dimensions to create innovation capacity. 
Innovation capacity as an outcome of MSMEs or characteristics of innovation capability of MSMEs is considered by the second line of research. With this perspective, innovation capacity is conceptualized as the ability to produce explicit types of innovation such as product innovation, process innovation, organizational innovation, marketing innovation, management innovation. Product innovation is the most researched (Çakar \& Ertürk, 2010; Chatzoglou \& Chatzoudes, 2018; Landoni et al., 2016). Next, organizational innovation was much less studied (Ali, Zwetsloot, \& Nada, 2019; David, Ryman, \& White, 2014). Production innovation capacity and process innovation capacity were also studied together (Wahyuni \& Sara, 2020). Most studies have identified and recognized innovation capacities through a combination of innovation capacity including product innovation, process innovation, organizational innovation, and marketing innovation (De Martino \& Magnotti, 2018; Kafetzopoulos \& Psomas, 2015; Kafetzopoulos \& Skalkos, 2019; Rajapathirana \& Hui, 2018). One study suggested that management innovation is the essential action and capability to implement innovation of any organization (MaldonadoGuzmán, Garza-Reyes, Pinzón-Castro, \& Kumar, 2019); divided innovation capacity into radical and incremental (Al-Ansari, Pervan, \& Xu, 2013; Lewrick, Chen, Raeside, \& Omar, 2012).

\subsection{Context}

Some studies have demonstrated that there are no substantial divergences in innovation capacity between the service and manufacturing sectors; between different sizes of business (Forsman, 2011; Saunila \& Ukko, 2014). Small firms have put more emphasis on leadership that supports innovation capacity (Saunila \& Ukko, 2014). In other words, small businesses are more innovative than medium businesses because small business managers pay attention to guide and lead employees to enhance innovation capacity.

The focus of the majority of research on innovation capacity for micro, small and medium enterprises in general (Al-Ansari et al., 2013; Castela et al., 2018; Saunila, 2017). On the other hand, empirical studies on innovation capacity in the manufacturing sector are also numerous (David et al., 2014; Kafetzopoulos \& Psomas, 2015; Rajapathirana \& Hui, 2018). The number of studies in each specific industry is also of considerable interest such as high-tech industry (Maldonado-Guzmán et al., 2019), food industry (De Martino \& Magnotti, 2018; Kafetzopoulos \& Skalkos, 2019), banking services (Baba, 2012), telecommunications industry (Abdulai Mahmoud \& Hinson, 2012); textile industry (Wahyuni \& Sara, 2020).

\subsection{Determinants of innovation capacity}

Based on the classification and concept above, the determinants of innovation capacity include a multi-aspect. The first research perspective shows that innovation capability in small businesses is determined by various dimensions. These key determinants include the ongoing learning of the organization, including managers and employees (Song, 2015); elements of knowledge, people and organizations (Martínez-Román et al., 2011); knowledge management (Raghuvanshi \& Garg, 2018); resources include knowledge and skills, involvement, networking (Raghuvanshi et al., 2019). Other considerable factors that create innovation capacity are considered strategic innovation including internal resources (humans, skills, cultural organizational structure, and technology) and external resources (suppliers, distributors, customers) and the collaborative factors of stakeholders such as employees, distributors, customers (Taneja et al., 2016).

Innovation capacity is also determined by two components: innovativeness and capacity to innovate collaborate with business strategy to improve business efficiency (Tamayo-Torres et al., 2016). Innovation capacity is recognized and identified through diverse types of innovation 
capabilities such as product, processes, organization, marketing, management, and networking.

\section{performance \\ 3.4. Research methodology and the relationship between innovation capacity and firm}

The majority of empirical studies performed quantitative research methods through surveys are chief executive officers, marketing managers, business expertise; business owners with a structured questionnaire after consulting experts (group discussion, hand-to-hand discussions, and collecting opinions via email) about the reality of the questionnaire, adjusting the questionnaire through the pilot test.

It is worth noting that the researchers and scholars in this article used the medium sample size from 436 samples (Kafetzopoulos \& Skalkos, 2019); 340 samples (Donkor et al., 2018) in view of Hair et al. (2006) to small sample size (115 samples) (Abdulai Mahmoud \& Hinson, 2012) for factor analysis, linear regression analysis by SPSS software. In addition, causal/causal model analysis by partial least squares PLS (Latan \& Ghozali, 2012) has been investigated by many researchers. The research is highly appreciated for its convenience and small sample sizes, such as Wahyuni and Sara (2020) using only 70 sample sizes for their research. In other cases, a relatively small number of samples (122 sample sizes) were also used in cluster analysis and one - way ANOVA and Post hoc Duncan test to identify the type of innovation capabilities in food firms (De Martino \& Magnotti, 2018).

Most studies emphasize the positive relationship between innovation capacity and firm performance in SMEs. The role of innovation capacity is the foremost contribution to the business results of the enterprise. Therefore, innovation capacity is discovered by many decisive factors such as organizational capacity, knowledge management (Chatzoglou \& Chatzoudes, 2018) to create a competitive advantage to help enhance business performance. table:

Based on the review, studies have found and confirmed relationships through the following

\section{Table 2}

Research methodology and the relationship between innovation capacity and firm performance

\begin{tabular}{|c|c|c|}
\hline Is & $\mathbf{p}$ & rs \\
\hline $\begin{array}{l}\text { testing, expert interviews, surveys, } \\
\text { factor analysis; T-test, correlation } \\
\text { regression analysis; decentralized } \\
\text { regression analysis; linear } \\
\text { regression } \\
\text { Tools: SPSS } \\
\text { Industry: single industry such as } \\
\text { telecommunications; high } \\
\text { technology; banking services; food } \\
\text { industry; Textile industry }\end{array}$ & \multirow{2}{*}{$\begin{array}{l}\text { Affirming the consequence of } \\
\text { innovation capacity assists managers } \\
\text { understand why innovation is } \\
\text { necessary; } \\
\text { - There is a positive contribution to } \\
\text { the correlation (positive correlation) } \\
\text { between market orientation, } \\
\text { corporate social responsibility and } \\
\text { innovation capacity (mediator } \\
\text { factor) and firm performance; or } \\
\text { quality orientation, knowledge } \\
\text { orientation in an uncertain business } \\
\text { environment. } \\
\text { - Affirming that many types of } \\
\text { innovation capabilities such as }\end{array}$} & $\begin{array}{l}\text { Abdulai Mahmoud and } \\
\text { Hinson (2012); Baba } \\
\text { (2012); Kafetzopoulos } \\
\text { and Psomas (2015); } \\
\text { Lewrick et al. (2012); } \\
\text { David et al. (2014); } \\
\text { Wahyuni and Sara } \\
(2020)\end{array}$ \\
\hline $\begin{array}{lr}\text { sting, expert commen } \\
\text { nail/group } & \text { discu }\end{array}$ & & $\begin{array}{l}\text { (2016); Al-Ansari et al. } \\
\text { (2013);Omri }\end{array}$ \\
\hline
\end{tabular}




\begin{tabular}{|l|l|l|}
\hline \multicolumn{1}{|c|}{ Research Methods } & \multicolumn{1}{|c|}{$\begin{array}{c}\text { The relationship between } \\
\text { innovation capacity and firm } \\
\text { performance }\end{array}$} & Authors \\
\hline $\begin{array}{l}\text { questionnaire surveys, factor } \\
\text { analysis, CFA, SEM; or PLS SEM } \\
\text { Analytical tools: SPSS or } \\
\text { SmartPLS }\end{array}$ & $\begin{array}{l}\text { product or service innovation } \\
\text { technological process innovation; } \\
\text { innovation management process; } \\
\text { organizational innovation; } \\
\text { Marketing innovation contributes to } \\
\text { business performance through } \\
\text { analysis and evaluation of non- } \\
\text { financial indicators such as customer } \\
\text { satisfaction, sales growth, profit } \\
\text { growth, market share or/and } \\
\text { financial criteria such as revenue, } \\
\text { profit level, ROS, ROI. }\end{array}$ & \\
\hline
\end{tabular}

Source: Summary of the author (2020)

\section{Conclusion and future research directions}

\subsection{Conclusions}

This review of empirical studies highlights five key issues in researching innovation capacity for SMEs. First, these empirical studies have illustrated that innovation capacity conceptualized either as the processor as the outcome, affects firm performance. Secondly, the number of empirical studies on innovation capacity in SMEs at this stage in a single sector is equivalent to that of many general industries. Third, there is more empirical research in the general and manufacturing sectors than in the service sector and there is a small amount of research comparing the characteristics of innovation capacity between manufacturing and services. Fourthly, the empirical researches focused mostly on the questionnaire survey, only a few studies have used qualitative research.

Finally, the empirical research group considers the innovation capacity as a process to confirm decisive factors such as knowledge factors (knowledge management, knowledge of managers, employees, suppliers, distributors) contribute to generating innovation capacity. Emphasizing the dominant mediator role of innovation capacity between market orientations, corporate social responsibility, and networking is a new and outstanding issue in the research that contributes to the success and growth of small businesses.

For practitioners, the findings have shown that small businesses could utilize numerous forms of innovation capabilities. Whilst some businesses can be able to create innovation capacity, others need to set up many different activities to take advantage of innovation. Truly, not all businesses receive optimal success from innovation, being able to innovate and innovation capacity. Therefore, business managers need to choose the right and appropriate aspect of the innovation capacity based on their specific business needs.

\subsection{Future research directions}

This review brings many directions for upcoming research. First, upcoming research needs to consider qualitative research instead of quantitative research using structured survey questionnaires. Second, upcoming innovation studies are more focused on the service sector or a combination of manufacturing and service sectors rather than on joint research or manufacturing. 
Further, the research can delve into how firm results can be affected in each type of innovation capacity; or more research on management process innovation capacity, process innovation capacity, and marketing innovation capacity. Further in-depth research can examine the mediator of specific types of innovation capacities in the relationship between many other factors such as customer orientation, or market orientation, or/and corporate social responsibility and / knowledge management and networking with business outcomes in terms of the supply chain perspectives.

Studies show that the method of collecting data using structured questionnaires has been used only for business owners, executives, marketing/sales/production/service/sales managers. There is a lack of surveys of suppliers, distributors, and customers to review the overall impact of innovation capacity on firm performance.

\section{References}

Agostini, L., Nosella, A., \& Soranzo, B. (2017). Measuring the impact of relational capital on customer performance in the SME B2B sector: The moderating role of absorptive capacity. Business Process Management Journal, 23(6), 1144-1166. doi:10.1108/BPMJ-10-2016-0205

Al-Ansari, Y., Pervan, S., \& Xu, J. (2013). Innovation and business performance of SMEs: The case of Dubai. Education, Business and Society: Contemporary Middle Eastern Issues, 6(3/4), 162-180. doi:10.1108/EBS-04-2013-0012

Ali, Z., Zwetsloot, I. M., \& Nada, N. (2019). An empirical study to explore the interplay of managerial and operational capabilities to infuse organizational innovation in SMEs. Procedia Computer Science, 158, 260-269. doi:10.1016/j.procs.2019.09.050

Baba, Y. (2012). Adopting a specific innovation type versus composition of different innovation types: case study of a Ghanaian bank. International Journal of Bank Marketing, 30(3), 218-240.

Bakar, L. J. A., \& Ahmad, H. (2010). Assessing the relationship between firm resources and product innovation performance: A re-source-based view. Business Process Management Journal, 16(3), 420-435.

Beaver, G., \& Prince, C. (2002). Innovation, entrepreneurship and competitive advantage in the entrepreneurial venture. Journal of Small Business and Enterprise Development, 9(1), 2837. doi:10.1108/14626000210419464

Boly, V., Morel, L., Assielou, N. D. G., \& Camargo, M. (2014). Evaluating innovative processes in french firms: Methodological proposition for firm innovation capacity evaluation. Research Policy, 43(3), 608-622. doi:10.1016/j.respol.2013.09.005

Budhwar, P., Pereira, V., Mellahi, K., \& Singh, S. K. (2019). The state of HRM in the Middle East: Challenges and future research agenda. Asia Pacific Journal of Management, 36(4), 905-933.

Çakar, N. D., \& Ertürk, A. (2010). Comparing innovation capability of small and medium-sized enterprises: Examining the effects of organizational culture and empowerment. Journal of Small Business Management, 48(3), 325-359.

Cardozo, R., McLaughlin, K., Harmon, B., Reynolds, P., \& Miller, B. (1993). Product-market choices and growth of new businesses. Journal of Product Innovation Management: An International Publication of The Product Development \& Management Association, 10(4), 331-340. 
Castela, B. M. S., Ferreira, F. A. F., Ferreira, J. J. M., \& Marques, C. S. E. (2018). Assessing the innovation capability of small-and medium-sized enterprises using a non-parametric and integrative approach. Management Decision, 56(6), 1365-1383. doi:10.1108/MD-02-2017-0156

Chatzoglou, P., \& Chatzoudes, D. (2018). The role of innovation in building competitive advantages: An empirical investigation. European Journal of Innovation Management, 21(1), 44-69. doi:10.1108/EJIM-02-2017-0015

Csath, M. (2012). Encouraging innovation in small and medium sized businesses: Learning matters. Development and Learning in Organizations: An International Journal, 26(5), 9-13.

David, C. R., Ryman, J., \& White, J. (2014). Culture, conduct and innovation: A deconstruction of market orientation. Journal of Research in Marketing and Entrepreneurship, 16(2), 128145. doi:10.1108/JRME-01-2014-0002

De Martino, M., \& Magnotti, F. (2018). The innovation capacity of small food firms in Italy. European Journal of Innovation Management, 21(3), 362-383.

Donkor, J., Donkor, G. N. A., Kankam-Kwarteng, C., \& Aidoo, E. (2018). Innovative capability, strategic goals and financial performance of SMEs in Ghana. Asia Pacific Journal of Innovation and Entrepreneurship, 12(2), 238-254. doi:10.1108/APJIE-10-2017-0033

Forsman, H. (2011). Innovation capacity and innovation development in small enterprises: A comparison between the manufacturing and service sectors. Research Policy, 40(5), 739750. doi:10.1016/j.respol.2011.02.003

Kafetzopoulos, D., \& Psomas, E. (2015). The impact of innovation capability on the performance of manufacturing companies. Journal of Manufacturing Technology Management, 26(1), 104-130.

Kafetzopoulos, D., \& Skalkos, D. (2019). An audit of innovation drivers: Some empirical findings in Greek agri-food firms. European Journal of Innovation Management, 22(2), 361-382. doi:10.1108/EJIM-07-2018-0155

Landoni, P., Dell'Era, C., Ferraloro, G., Peradotto, M., Karlsson, H., \& Verganti, R. (2016). Design contribution to the competitive performance of SMEs: The role of design innovation capabilities. Creativity and Innovation Management, 25(4), 484-499.

Lewrick, M., Chen, T., Raeside, R., \& Omar, M. (2012). Exploration of innovation capabilities of firms in Liaoning and Henan provinces. Journal of Science and Technology Policy in China, 3(3), 242-263. doi:10.1108/17585521211268691

Mahmoud, M. A., \& Hinson, R. E. (2012). Market orientation, innovation and corporate social responsibility practices in Ghana's telecommunication sector. Social Responsibility Journal, 8(3), 327-346. doi:10.1108/17471111211247910

Maldonado-Guzmán, G., Garza-Reyes, J. A., Pinzón-Castro, S. Y., \& Kumar, V. (2019). Innovation capabilities and performance: Are they truly linked in SMEs? International Journal of Innovation Science, 11(1), 48-62. doi:10.1108/IJIS-12-2017-0139

Martínez-Román, J. A., Gamero, J., \& Tamayo, J. A. (2011). Analysis of innovation in SMEs using an innovative capability-based non-linear model: A study in the province of Seville (Spain). Technovation, 31(9), 459-475. doi:10.1016/j.technovation.2011.05.005

Naranjo-Valencia, J. C., Jiménez-Jiménez, D., \& Sanz-Valle, R. (2016). Studying the links between organizational culture, innovation, and performance in Spanish companies. Revista Latinoamericana de Psicología, 48(1), 30-41. doi:10.1016/j.rlp.2015.09.009

Omri, W. (2015). Innovative behavior and venture performance of SMEs: The moderating effect 
of environmental dynamism. European Journal of Innovation Management, 18(2), 195-217. doi:10.1108/EJIM-02-2013-0015

Raghuvanshi, J., \& Garg, C. P. (2018). Time to get into the action: Unveiling the unknown of innovation capability in Indian MSMEs. Asia Pacific Journal of Innovation and Entrepreneurship, 12(3), 279-299. doi:10.1108/APJIE-06-2018-0041

Raghuvanshi, J., Agrawal, R., \& Ghosh, P. K. (2019). Measuring the innovation capability of micro enterprises in India: Construct development and validation. Benchmarking: An International Journal, 26(5), 1405-1430. doi:10.1108/BIJ-08-2018-0229

Rajapathirana, R. P. J., \& Hui, Y. (2018). Relationship between innovation capability, innovation type, and firm performance. Journal of Innovation \& Knowledge, 3(1), 44-55. doi:10.1016/j.jik.2017.06.002

Sandvik, I. L., \& Sandvik, K. (2003). The impact of market orientation on product innovativeness and business performance. International Journal of Research in Marketing, 20(4), 355-376.

Saunila, M. (2017). Understanding innovation performance measurement in SMEs. Measuring Business Excellence, 21(1), 1-16.

Saunila, M., \& Ukko, J. (2014). Intangible aspects of innovation capability in SMEs: Impacts of size and industry. Journal of Engineering and Technology Management, 33, 32-46. doi:10.1016/j.jengtecman.2014.02.002

Song, Z.-h. (2015). Organizational learning, absorptive capacity, imitation and innovation: Empirical analyses of 115 firms across China. Chinese Management Studies, 9(1), 97-113. doi:10.1108/CMS-05-2014-0092

Tamayo-Torres, I., Gutiérrez-Gutiérrez, L. J., Llorens-Montes, F. J., \& Martínez-López, F. J. (2016). Organizational learning and innovation as sources of strategic fit. Industrial Management \& Data Systems, 116(8), 1445-1467. doi:10.1108/IMDS-12-2015-0518

Taneja, S., Pryor, M. G., \& Hayek, M. (2016). Leaping innovation barriers to small business longevity. Journal of Business Strategy, 37(3), 44-51. doi:10.1108/JBS-12-2014-0145

Utterback, J. (1994). Mastering the dynamics of innovation: How companies can seize opportunities in the face of technological change. Boston, MA: Havard Business Press.

Wahyuni, N. M., \& Sara, I. M. (2020). The effect of entrepreneurial orientation variables on business performance in the SME industry context. Journal of Workplace Learning, 32(1), 35-62. doi:10.1108/JWL-03-2019-0033

Weerawardena, J., \& O'Cass, A. (2004). Exploring the characteristics of the market-driven firms and antecedents to sustained competitive advantage. Industrial Marketing Management, 33(5), 419-428.

Yildiz, H. E., Murtic, A., Klofsten, M., Zander, U., \& Richtnér, A. (in press). Individual and contextual determinants of innovation performance: A micro-foundations perspective. Retrieved May 11, 2020, from https://www.researchgate.net/publication/343451600_ Individual_and_contextual_determinants_of_innovation_performance_A_micro_foundations_perspective

Zheng, Y., Liu, J., \& George, G. (2010). The dynamic impact of innovative capability and interfirm network on firm valuation: A longitudinal study of biotechnology start-ups. Journal of Business Venturing, 25(6), 593-609. 